Original Research

\title{
Arkansas pharmacists' perceptions toward emergency contraception and nonprescription Plan B
}

\author{
Received (first version): 1 -Feb-2008 \\ Accepted: 27-May-2008
}

\begin{abstract}
${ }^{*}$
Objective: This study describes Arkansas

pharmacists' knowledge, attitudes, and beliefs regarding emergency contraception.

Methods: A cross-sectional survey was conducted among a convenience sample of pharmacists prior to a continuing education lecture. The 16-item survey included multiple choice and true/false questions to assess knowledge in addition to Likerttype scale questions regarding attitudes and beliefs. Frequency and descriptive statistics were calculated for all variables.

Results: Eighty-eight pharmacists completed the survey. A majority (73\%) knew that Plan B had been FDA-approved for nonprescription use yet $42 \%$ believed that it works by disrupting a newly implanted ovum. On a scale from 1-5 where $5=$ strongly agree, the mean item score was 3.2 for whether emergency contraception should be available for nonprescription use with counseling and 1.6 for nonprescription use without counseling. When asked what they would do if presented with a request for emergency contraception, $45.8 \%$ indicated they would dispense the drug, $22.9 \%$ would refer the patient to another pharmacist or pharmacy, $3.6 \%$ would refuse to dispense, and $27.7 \%$ were not sure. Almost half $(48.6 \%)$ did not believe they were competent instructing patients on the use of emergency contraception.

Conclusions: The results show that pharmacists could benefit from additional training on emergency contraception.
\end{abstract}

Keywords: Contraception, Postcoital. Pharmacists. Attitude of Health Personnel. United States.

\footnotetext{
*Denise HOPKINS, PharmD. Assistant Professor. College of Pharmacy, University of Arkansas for Medical Sciences. Little Rock, Arkansas (USA).

Donna WEST, PhD. Associate Professor. College of Pharmacy, University of Arkansas for Medical Sciences. Little Rock, Arkansas (USA).
}

\author{
PERCEPCIONES DE LOS \\ FARMACÉUTICOS DE ARKANSAS SOBRE \\ LA CONTRACEPCIÓN DE EMERGENCIA Y \\ EL PLAN B SIN RECETA
}

\section{RESUMEN}

Objetivo: Este estudio describe el conocimiento, las actitudes y las creencias de los farmacéuticos de Arkansas sobre contracepción de emergencia. Métodos: Se realizó un estudio transversal en una muestra de conveniencia de farmacéuticos antes de una sesión de formación continuada. La encuesta incluía 16 preguntas de elección múltiple y de verdadero/falso para evaluar el conocimiento, además de preguntas con escala tipo Likert sobre actitudes y creencias. Se calculó la frecuencia y la estadística descriptiva para todas las variables. Resultados: 88 farmacias completaron el cuestionario. La mayoría (73\%) sabía que el Plan B había sido aprobado por la FDA para uso sin receta, aunque el $42 \%$ creía que funcionaba despegando un ovulo implantado. En una escala de 1 a 5 , donde $5=$ fuertemente de acuerdo, la puntuación media del punto sobre si la contracepción de emergencia debía ser disponible sin receta con consejo fue de 3,2 y de 1,6 para contracepción de emergencia sin receta y sin consejo. Cuando se preguntó que harían si recibían una receta para una contracepción de emergencia, el 45,8\% indicó que la dispensaría, el 22,9 referiría al paciente a otro farmacéutico o farmacia, el 3,6\% recusaría dispensarla, y el 27,7\% no estaba seguro. Casi la mitad $(48,6 \%)$ no se creía competente para educar al paciente en el uso de la contracepción de emergencia.

Conclusiones: Los resultados muestran que los farmacéuticos podrían beneficiarse de formación adicional sobre contracepción de emergencia.

Palabras clave: Contracepción postcoital. Farmacéuticos. Actitudes del personal sanitario. Estados Unidos.

\section{INTRODUCTION}

It is generally accepted that emergency contraception is a safe and effective method of preventing pregnancy. ${ }^{1,2}$ Appropriate use of emergency contraception has the potential to prevent up to $75 \%$ of unplanned pregnancies ${ }^{3}$, yet approximately 3.5 million unintended pregnancies occur each year in the United States. ${ }^{4}$ Although the 
reasons for this alarming statistic have not been fully determined, barriers to the appropriate use of emergency contraception may be a contributing factor.

Significant barriers to the appropriate use of emergency contraception include lack of patient awareness, lack of patient access, lack of product availability, and lack of provider awareness. The August 24, 2006 decision by the U.S. Food and Drug Administration (FDA) to approve nonprescription sales of the emergency contraceptive Plan $\mathrm{B}^{\mathrm{TM}}$ mitigated some of these barriers. This dedicated product, $1.5 \mathrm{mg}$ of levonogrestrel taken after unprotected or inadequately protected intercourse, is now available without a prescription for females and males 18 years or older. Distribution of Plan $\mathrm{B}^{\mathrm{TM}}$ is through pharmacies and clinics with licensed healthcare professionals. It is stocked behind the counter in pharmacies because it cannot be dispensed without a prescription or proof of age.

Pharmacists are now positioned to play a pivotal role in the provision of emergency contraception and patient education. Yet their knowledge, attitudes, and experience with emergency contraception may influence the service they provide. Previous studies have shown that pharmacists have generally average knowledge of emergency contraception and do not strongly support nonprescription status for emergency contraception. ${ }^{5,6}$ However, these surveys were conducted prior to the FDA approving behind-thecounter access of Plan B ${ }^{\mathrm{TM}}$. With this FDA approval and the lay press publicity of its availability through a pharmacy/pharmacist, pharmacists will be a key access point for patients. Thus, the purpose of this study is to describe Arkansas pharmacists' knowledge, attitudes, and behaviors with respect to emergency contraception, since the FDA approval of nonprescription sales of Plan $\mathrm{B}^{\mathrm{TM}}$.

\section{METHODS}

This study was approved by the University of Arkansas for Medical Sciences Institutional Review Board (IRB). Pharmacists attending the Arkansas Association of Health-System Pharmacists (AAHP) fall meeting in October 2006 were selected as the convenience population to study. A cross-sectional survey was conducted. An information sheet and survey were distributed to all attendees. Pharmacists were asked to complete the survey voluntarily and anonymously prior to a continuing education session on emergency contraception. Attendees were given a short time period to complete the survey and then completed surveys were collected. After all completed surveys were collected, the continuing education session began.

The investigators used a self-administered questionnaire to collect the data. A 16-question survey was constructed by the investigators to assess knowledge, attitudes, and behaviors about emergency contraception. The survey questions included the following categories.
- Multiple choice and true/false questions were used to assess knowledge about emergency contraception. The knowledge questions were adapted from a previous study evaluating physician knowledge of emergency contraception. ${ }^{7}$

- Attitudes and beliefs toward emergency contraception were measured using a 5-point Likert-type scale, where $1=$ strongly disagree and $5=$ strongly agree. These items were adapted from a previous emergency contraception study. $^{7}$

- In addition to understanding the pharmacists' knowledge and attitudes, the investigators were interested in pharmacist behavior and experience with emergency contraception. Three questions pertained to the pharmacist's self-reported emergency contraception dispensing experience (i.e., does the pharmacy stock it, has pharmacist dispensed it, behavioral intention if presented with request today).

- General demographic information questions (gender, age, religious affiliation, primary practice setting and position) were included on the survey.

A pharmacist with a national reputation for his expertise in the area of emergency contraception was asked to evaluate the survey for content relevance and completeness, in an attempt to ensure content validity. The survey was then pretested by four pharmacy practice faculty of the University of Arkansas for Medical Sciences to ensure all questions were understandable. The survey was revised based on their comments and questions. The surveys by the faculty were excluded from the results analysis.

The surveys were tabulated and the data were entered into a database. Frequencies and descriptive statistics were calculated using SPSS 14.0 (Chicago, IL).

\section{RESULTS}

Eighty-eight pharmacists completed the survey; however, there are missing data points as some respondents did not answer certain questions. Three respondents did not answer the demographic information. Of those completing the demographic section ( $\mathrm{N}=85), 51 \%$ were male. The majority of participants $(42 \%)$ were 50 years of age or older; $33 \%$ were 39 years of age or younger; and $25 \%$ were between the ages of 40 to 49 years of age inclusive. Ninety-three percent of participants indicated they were Christian, and of those $86 \%$ were non-Catholic and $14 \%$ were Catholic. Subjects' primary practice sites included $74 \%$ hospital and $26 \%$ retail, clinic, or "other."

A majority (62 of 85 respondents) knew that Plan $\mathrm{B}^{\mathrm{TM}}$ had been FDA-approved for nonprescription use by females age 18 or older. However, 39 of the 85 answering the question (46\%) incorrectly identified Plan B ${ }^{\mathrm{TM}}$ as RU486 (mifepristone) and 36 $(42.4 \%)$ believed that emergency contraception works by disrupting a newly implanted ovum. Only 
five of 86 respondents (6\%) knew that emergency contraception may be effective if started within 120 hours of unprotected intercourse. ${ }^{8,9}$ In addition, $72.4 \%$ (63 of 87 ) correctly answered that Arkansas pharmacists have a legal right to refuse to dispense emergency contraception based on moral or religious beliefs. ${ }^{10}$

When asked about attitudes toward emergency contraception, most mean ratings were neutral, as shown in Table 1. Pharmacists did disagree with the one item pertaining to emergency contraception being available without required counseling by the pharmacist. When looking at the responses for each item, about one-third disagreed, one-third were neutral, and one-third agreed that nonprescription emergency contraception will promote unsafe sex and will discourage regular contraception use. When asked if they were uncomfortable dispensing emergency contraception for moral or religious reasons, few participants were neutral, with 36 participants agreeing that they were uncomfortable and 36 participants disagreeing. Only $33.8 \%$ agreed that they felt competent instructing patients regarding the appropriate use of emergency contraception.

Table 1: Attitudes toward emergency contraception of Arkansas Pharmacists

\begin{tabular}{|l|c|c|c|c|c|c|}
\hline \multicolumn{1}{|c|}{ Item evaluated } & $\mathrm{N}$ & Mean* & $\begin{array}{c}\text { Std } \\
\text { Dev }\end{array}$ & $\begin{array}{c}\% \text { Disagre } \\
\text { (1 or 2 Rating) }\end{array}$ & $\begin{array}{c}\% \text { Neutral } \\
\text { (3 Rating) }\end{array}$ & $\begin{array}{c}\text { \% Agree } \\
\text { (4 or 5 Rating) }\end{array}$ \\
\hline $\begin{array}{l}\text { Emergency contraception should be } \\
\text { available for nonprescription use WITH } \\
\text { required counseling by pharmacist. }\end{array}$ & 84 & 3.2 & 1.5 & $34.5 \%$ & $9.5 \%$ & $55.9 \%$ \\
\hline $\begin{array}{l}\text { Emergency contraception should be } \\
\text { available for nonprescription use } \\
\text { WITHOUT required counseling by } \\
\text { pharmacist. }\end{array}$ & 85 & 1.6 & 1.1 & $83.5 \%$ & $9.4 \%$ & $7.1 \%$ \\
\hline $\begin{array}{l}\text { Nonprescription emergency } \\
\text { contraception will promote unsafe sex. }\end{array}$ & 85 & 3.0 & 1.4 & $38.9 \%$ & 27.1 & 34.1 \\
\hline $\begin{array}{l}\text { Nonprescription emergency } \\
\text { contraception will discourage regular } \\
\text { contraception use. }\end{array}$ & 85 & 3.1 & 1.3 & $37.6 \%$ & 22.4 & 40.0 \\
\hline $\begin{array}{l}\text { I am uncomfortable dispensing } \\
\text { emergency contraception for moral or } \\
\text { religious reasons }\end{array}$ & 86 & 3.0 & 1.6 & $41.9 \%$ & $16.3 \%$ & $41.8 \%$ \\
\hline $\begin{array}{l}\text { I feel competent instructing patients } \\
\text { regarding the appropriate use of } \\
\text { emergency contraception. }\end{array}$ & 86 & 2.9 & 1.3 & $38.4 \%$ & $27.9 \%$ & $33.8 \%$ \\
\hline *on a scale from 1-5, where 1=strongly disagree and 5=strongly agree & & & \\
\hline
\end{tabular}

Almost a fourth $(22.6 \%$ or 19 of 84 respondents to the question) had dispensed emergency contraception, and $4 \%$ had referred a patient to another pharmacist or pharmacy to obtain emergency contraception. The majority (74\%) had never received a prescription or request for emergency contraception. Similarly, the majority $(51.8 \%$ or 44 of 85$)$ of the participants work in pharmacies that do not currently stock Plan B ${ }^{\mathrm{TM}}$. Almost a fourth $(23.5 \%)$ work in pharmacies that currently stock Plan $\mathrm{B}^{\mathrm{TM}}$ and $5 \%$ indicated that they do not stock it but could obtain it within 24 hours. The other $20 \%$ were not sure if the pharmacy stocked it or indicated that question was not applicable to their employment. Eighty-three participants indicated what they would do if presented with a request for emergency contraception, with $45.8 \%$ indicated they would fill the prescription, $22.9 \%$ would refer the patient to another pharmacist or pharmacy, $3.6 \%$ would refuse to dispense, and $27.7 \%$ were not sure.

\section{DISCUSSION}

Most of the pharmacist participants were aware that Plan $\mathrm{B}^{\mathrm{TM}}$ had been FDA-approved for behind-thecounter sales. Now that Plan $B^{T M}$ has nonprescription status, access will rely more on pharmacists. Thus the pharmacists' stocking of the product, ability to counsel patients, and acceptance of nonprescription status will have important implications for patient access to emergency contraception. However, knowledge of emergency contraception and attitudes toward emergency contraception in this study were similar to the results of studies conducted prior to the behind-thecounter switch.

It is important for pharmacists to be aware and knowledgeable of emergency contraception to help women use it effectively. Pharmacists are likely to be the point of contact with the health care system for not only Plan B ${ }^{\mathrm{TM}}$ but information about it. These study results suggest that pharmacists could benefit from additional training on EC and proper counseling for emergency contraception. Results for the knowledge questions indicate that pharmacists have average knowledge of emergency contraception. These findings are similar to the findings from pharmacy surveys about emergency contraception as well as physician surveys about emergency contraception. ${ }^{5-7}$

It is also interesting to note that pharmacists agreed if nonprescription emergency contraception is available that patients should receive counseling from a pharmacist. Unfortunately, only one-third of the pharmacists surveyed indicated they were comfortable providing counseling regarding Plan $\mathrm{B}^{\mathrm{TM}}$. It appears that there is an opportunity for additional training in emergency contraception, 
specifically about Plan $\mathrm{B}^{\mathrm{TM}}$. Pharmacists do want to provide education to their patients about Plan $\mathrm{B}^{\mathrm{TM}}$ when they dispense it. The results of this study can help in the design of better educational programs for pharmacists, given the wide range of attitudes and experiences with emergency contraception.

Approximately $40 \%$ of the participants were not comfortable dispensing emergency contraception because of moral or religious reasons. This finding confirms the results of the other pharmacist surveys that identified moral and religious reasons as barriers to dispensing emergency contraception. ${ }^{5,7}$ It is possible that this response was based on misinformation as $46 \%$ incorrectly identified Plan $\mathrm{B}^{\mathrm{TM}}$ as RU486 (mifepristone) and $42.4 \%$ believed that emergency contraception works by disrupting a newly implanted ovum. It is important to remember that others factors like pharmacist education and practice setting equally influence the dispensing of $\mathrm{EC}$ and can be barriers or facilitators as well. ${ }^{5}$

Overall, the attitudes toward emergency contraception were reflected in their behaviors and behavior intentions. Only a few participants had refused to dispense or referred a patient to another pharmacy or pharmacist. About half of the pharmacies currently stocked Plan $B^{T M}$. Now that Plan $\mathrm{B}^{\mathrm{TM}}$ is available OTC, it would be interesting to investigate further the practice environment of the pharmacies that stock the product and their policies and procedures for stocking and dispensing the product.

When asked what they would do if presented with a request for emergency contraception, about half of the pharmacists indicated they would dispense it. Approximately one-fourth were not sure. Possible reasons for this uncertainty may include: lack of knowledge about the product; lack of comfort counseling patients about emergency contraception; pharmacy employer does not stock emergency contraception; or other barriers such as religious or moral reasons. Again, these results highlight the need for pharmacists to be provided continuing education about emergency contraception products as well as appropriate counseling methods. It is suggested that if pharmacists feel competent counseling patients about the product and pharmacies stock the product, pharmacists will provide the necessary access to emergency contraception and ensure its appropriate use.

A nationwide survey would be helpful to understand pharmacists' attitudes and behaviors with respect to emergency contraception. Repeating the survey now as Plan $\mathrm{B}^{\mathrm{TM}}$ as a nonprescription product is widely available would help us understand pharmacists' experiences with providing it and counseling patients about its appropriate use.

Not unlike others, this study has limitations. The study utilized a cross-sectional convenience sample rather than a random sampling technique. Thus, the findings of the survey may not be generalizeable to other Arkansas pharmacists, pharmacists in other states, or other health care professionals. This survey sample was $74 \%$ hospital-based pharmacists. It is possible that a convenience sample of retail-based pharmacists would have vastly different results. Even comparing these results to a survey of the same group after the continuing education program would likely yield different results. Unfortunately, a post- continuing education program survey was not possible due to time constraints.

\section{CONCLUSIONS}

A survey of knowledge, attitudes, and beliefs towards emergency contraception was conducted among Arkansas pharmacists. Misinformation regarding this method of contraception was common among this convenience sample. Attitudes and beliefs varied widely and almost half reported that they did not feel competent providing emergency contraception counseling. The results show that pharmacists could benefit from additional training on emergency contraception.

\section{ACKNOWLEDGEMENTS}

The authors wish to acknowledge Don Downing for his guidance in the project.

\section{CONFLICT OF INTEREST}

The authors have no conflicts of interests to disclose. No funding was received to conduct this study.

\section{References}

1. Emergency Contraception. ACOG Practice Bulletin No. 69. American College of Obstetrics and Gynecologists. Obstet Gynecol 2005;106:1443-1452.

2. Emergency Contraception. Committee on Adolescence. Pediatrics 2005;116;1026-1035

3. Trussell J, Rodriquez G, Ellertson C. Updated estimates of the effectiveness of the Yuzpe regimen of emergency contraception. Contraception 1999:59:147-151

4. Henshaw SK, Unintended pregnancy in the United States. Fam Plann Perspective 1998;30:24-9,46

5. Borrego ME, Short J, House N, Gupchup G, Naik R, Cuellar D. New Mexico pharmacists' knowledge, attitudes, and beliefs toward prescribing oral emergency contraception. J Am Pharm Assoc 2006;46:33-43.

6. Sutkin G, Grant B, Irons B, Borders T. Opinions of West Texas Pharmacists about Emergency Contraception. Pharm Pract (Internet) 2006;4(4):151-155.

7. Wallace JL, Wu J, Weinstein J, Gorenflo DW, Fetters MD. Emergency contraception: Knowledge and attitudes of family medicine providers. Fam Med 2004;36(6):417-422

8. Ellerson C, Evans M, Ferden S, et al. Extending the time limit for starting the Yuzpe regimen of emergency contraception to 120 hours. Obstet Gynecol 2003;101:1168-1171. 
Hopkins D, West D. Arkansas pharmacists' perceptions toward emergency contraception and nonprescription Plan B. Pharmacy Practice 2008 Apr-Jun;6(2):98-102.

9. Rodrigues I, Grou F, Jolly J. Effectiveness of emergency contraceptive pills between 72 and 120 hours after unprotected sexual intercourse. Am J Obstet Gynecol 2001;184:531-534.

10. Hopkins D, Boss M. Pharmacists' right to refuse to dispense prescriptions based on moral grounds; a national survey of state laws and regulations. Hosp Pharm 2006;4(12);1176-1179. 